\title{
Osmanlı Donanması Askerlerinin Tayyarelerde Görevlendirilmek Üzere Yetiştirilmesi
}

\section{Training of Ottoman Naval Soldiers to be Employed in Airplanes}

\author{
Derya Geçili [
}

'Dr., Niğde Ömer Halisdemir Üniversitesi Rektörlüğü, Atatürk Illkeleri ve Inkılap Tarihi Bölümü, Niğde, Türkiye

\section{ORCID: D.G. 0000-0003-2769-1713}

\section{Sorumlu yazar/Corresponding author:} Derya Geçili,

Niğde Ömer Halisdemir Üniversitesi Rektörlüğü, Atatürk IIlkeleri ve İnkılap Tarihi Bölümü, Niğde, Türkiye

E-mail/E-posta: degecili@hotmail.com

Başvuru/Submitted: 05.03.2019 Revizyon Talebi/Revision Requested: 03.04.2019

Son Revizyon/Last Revision Received: 29.04.2019

Kabul/Accepted: 06.05.2019

Online Yayın/Published Online: 03.07 .2019

\section{Atıf/Citation:}

Geçili, Derya. "Osmanlı Donanması Askerlerinin Tayyarelerde Görevlendirilmek Üzere Yetiștirilmesi." Osmanlı Bilimi Araștırmaları 20, 2 (2019): 103-114 https://doi.org/10.26650/oba.536002

\section{öz}

İnsanoğlu, ihtiyaçları nispetinde kara, deniz ve demir yollarını kullanmıştır. Hava ulaşımındaki gelişmeler yeni bir devrin başlangııını teşkil etmiştir. Osmanlı Devleti, tayyarelerin askeri alandaki önemini, İtalya'nın Osmanlı mevzilerini tayyarelerle bombalamasıyla, Trablusgarp Savaşı (1911-1912) sırasında anlamış, Avrupa devletlerinden satın aldığı uçaklarla hava gücünü oluşturmaya çalışmıştır. Tayyareler, sadece karada değil zamanla denizlerde de etkili işlev görmüştür. Savaş sırasında düşman mevkilerini, kuvvetlerini, birliklerini, seyir ve hareketlerini mümkün olduğu kadar seri ve tam anlamıyla öğrenilebilmek, donanmalar için büyük öneme sahipti. Osmanlı Deniz Kuvvetleri, tayyarelerde görevli mühendis ve rasatçılara yardımcı olacak askere intiyaç duymuştur. Donanmaya bağlı Efrad-ı Cedide Mektebi'nde eğitim alan askerlerin bir kısmı 'tayyareci askeri' veya 'tayyareci efrad' olarak yetiştirilerek eleman açığı kapatılmaya çalışılmıştır. Bu çalışmada, Osmanlı donanma askerlerinin 'tayyareci asker' olarak yetiştirilme süreci incelenmiştir. Anahtar sözcükler: Deniz tayyareleri, tayyare askerleri, Osmanlı donanması

\section{ABSTRACT}

Highways, maritime lines and railways were developed to meet the needs of humanity. Advances in aerial transportation heralded a new era. The Ottoman State realized the importance of airplanes when the Italians used them to bomb Ottoman positions during the Tripoli War (1911-1912). Consequently, work was undertaken to establish air forces by purchasing airplanes from European states. Airplanes were essential not only for land forces but also for the navy to accurately track the position and movement of enemy forces. After attending Efrad-ı Cedide Mektebi (the School of New Soldiers established within the Ottoman Naval Forces), Ottoman soldiers, were trained in special courses to become 'airplane soldiers' (tayyareci efrad, tayyareci asker) in order to assist the engineers (mühendis) and observers (rasatçı) in charge of airplanes. The aim of the present article is to study the training of these soldiers to be employed later on in the airplanes of the Ottoman navy.

Keywords: Airplanes, airplane soldiers, training, Ottoman navy 


\section{Giriş}

Gemiler, çok eski zamanlardan beri taşımacılıkta büyük bir öneme sahip olmuştur. Gemilerle kıtalar arasında ticaret malları çok kısa bir zamanda birbirlerine ulaştırılabiliyordu. Dünyada meydana gelen değişimler sonucunda gemiler, savaşlarda da kullanılmaya başlamıştı. Bir süre sonra savaş gemileri, istila ve yok etmek amacıyla kullanılan müthiş bir silah haline geldi. Avrupalı devletler, büyük servetler harcayarak meydana getirdikleri bu silahta bazı değişiklikler yaptılar. Ayrıca, savaş gemilerinin inşası ve satılması konusunda da büyük bir rekabete giriştiler. Böylece, savaş gemilerinde sürekli değişimler yapılarak dretnot adı verilen gemiler inşa edilmiştir. Ancak, bir süre sonra savaş gemilerindeki bu değişimler ve yenilikler sona ermiştir. Çünkü büyük ve güçlü dretnotlara karşı onun ancak direk ve bacası değerinde olabilen tayyareler keşfedilmiştir. Dretnot kendisinden oldukça küçük ve önemsiz olan tayyare karşısında hiçbir şey yapamıyordu. Hatta tayyarenin saldırılarından birkaç dakika sonra denize batabiliyordu. Gemilerde yapılan bütün önlemlere ve yenliklere rağmen bu tehlikeli silaha karşı bir şey bulunamadı. Tayyareler, denizaltılar içinde fazlasıyla tehlikeli olmuştu. Tayyare hücumuna maruz kalan denizaltılardan yüzde doksan dokuz nispetinde ümitler kesiliyordu. ${ }^{1}$ Avrupalı devletler, gemicilikte gösterdikleri gayreti ve rekabeti, tayyarecilikte yapmaya başlamışlardı. Deniz savaşlarında daha rahat hareket edebilecek deniz tayyareleri inşa etmişlerdi. ${ }^{2}$

Büyük devletlerin deniz kuvvetlerinde tayyareleri kullanmaları, coğrafi durumları ve hükümetlerin amaçlarına göre farklılık göstermiştir. ${ }^{3}$ İngiltere, Amerika gibi büyük devletlerin donanmaları tayyarelerinden faydalanmakla birlikte, tayyareleri askeri amaçlar için kullanmada İtalya'nın öncülük ettiği bilinmektedir. İtalyanlar, Trablusgarp Savaşı sırasında hem keşif hizmeti hem de hava bombardımanı için 1911 yılında tayyareleri kullanmışlardır. Bu durum, Osmanlı yöneticilerinin tayyarelerin askeri önemini fark etmesini sağlamış ve Osmanlı hava gücünü kurma konusunda çalışmalara başlanmıştır. ${ }^{4}$ İlk olarak, iki Osmanlı zabiti pilotluk eğitimi almak için Paris’te bulunan sivil Blériot Havacılık Okulu'nda tayyarecilik öğrenimine gönderilmiştir. Pilotlar Fransa'da eğitim görürken, İstanbul'da orduda hava gücünü kurmak için ilk adımlar atılmıştır. Erkan-1 Harbiye Miralayı Süreyya Bey (İlmen) havacılık teşkilatının oluşturulmasıyla görevlendirilmiştir. ${ }^{5}$ Bu doğrultuda 1911 yılında ilk Tayyare Komisyonu kurulmuş ve 1912 yılında ise Yeşilköy’de Tayyare Mektebi açılarak pilot ve rasıtlar (gözleyici) yetiştirilmeye başlanmıştır. ${ }^{6}$

\footnotetext{
1 “Gemiden Sonra Tayyare,” Tayyare Cemiyeti Mecmuası 17, 23 (1 Mart 1926): 3-4.

"Hava Devri," Tayyare Cemiyeti Mecmuass 17/11 (1 Kanun-i evvel 1925): 1-2.

“Bahri Tayyareler," Donanma 40 (Şaban 1332 / 29 Haziran 1914): 5.

"Tayyarelerin Ehemmiyet-i Harbiyeleri," Ordu ve Donanma Dergisi sayı 2 (Nisan 1328 / 1912): 43.

Mustafa Yeni, "Hava Kuvvetleri,” Dünya Savaş Tarihi: Osmanlı Askeri Tarihi, ed. Gültekin Yıldız (İstanbul: Timaş Yayınları, 2013), 165.

6 Deniz Kurt ve Erdal Korkmaz, "Yeni Arşiv Belgeleri Işı̆̆ında Türk Askerî Havacılığının Doğuşu (19111912)," Savunma Bilimleri Dergisi 17, 2 (2018): 207-251.
} 
Osmanlı Devleti'nde başlayan yenilik hareketleri sonucunda Avrupa'dan modern savaş gemileri satın alındığı gibi, Avrupa usullerine uygun modern savaş gemileri de inşa edilerek imparatorluğun deniz gücü etkinleştirilmişti. ${ }^{7}$ Aynı zamanda, bu gemileri bilinçli bir şekilde kullanabilecek iyi yetiştirilmiş personele ihtiyaç olduğu gözden kaçmamıştı. ${ }^{8}$ Yeni savaş gemilerinde gerek güverte ve gerekse makine hizmetinde özellikle fen ile sanayi eğitimine ihtiyaç duyulmaktaydı. Gemi komutanından dümen erine kadar bütün askerlerin sorumluluk almadan önce iyi bir teknik eğitime tabi tutulmaları gerekmekteydi. ${ }^{9}$ Donanmada görevlendirilen askerler güverte ve makine olarak iki sınıfa ayrılmıştı. Güverte sınıfı, efrad, gedikli, ${ }^{10}$ gemici ve telsiz-telgrafçı gibi bölümlerden oluşuyordu. Tayyarelerinin kullanılmaya başlanması ile tayyareciler de güverte sınıfına dâhil edildi. Yetiştirilmek üzere 1911'de Fransa ve İngiltere'ye gönderilen öğrenciler, Balkan Savaşları çıkınca geri çağrılarak savaşlara katıldılar. Kasımpaşa'daki kışla 1910-1911 yıllarında denizci askerlerin eğitimi için Bahriye Efrad-1 Cedide Mektebi Müdüriyeti'ne verildi. ${ }^{11}$ Mektepte, donanma askerleri bir sene ders gördükten sonra sınava tabi tutulmaktaydı. Bu sınavın sonunda başarılı olan askerler, deniz tayyarelerde görevlendirilmek üzere yetiştirilmek amacıyla kurslara gönderildiler. Aşağıda, Efrad-1 Cedide ve Gedikli mekteplerinden çıkan donanma askerlerinin tayyarecilik kurslarına gönderilerek yetiştirilme süreci işlenmiştir.

\section{Donanma Askerlerinin Yetiştirilmesi}

1917 yılının son günlerinde yayımlanan "Bahriye Efradı ve Küçük Zabitanıyla Gedikli Zabitanına Dair 22 Rebiyülahir 1333 [9 Mart 1915] Tarihli Kanunun 1. Maddesini Muadil Kanun" ile birlikte donanma askerlerinin (bahriye efradı ve gediklileri) Deniz Kuvvetlerine kabulü, yetiştirilmeleri, izinleri ve terfileri belli kurallara bağlanmıştır. ${ }^{12}$ Bu kanuna göre, donanma askeri olmak isteyen aday on sekiz yaşını tamamlamış, ilkokul mezunu, okuryazar ve iyi ahlak sahibi olmalıdır. Ayrıca sağlıklı ve vücut yapısı güçlü olmalıdır. Aday, görev için yeterli olduğunun belirlenmesi için hastanede sağlık kontrolünden geçer. Göze çarpacak bir hastalığı, bedeninde bir kusuru, zihinsel algılama sorunu varsa, ya da yaşı bu mesleğe uygun değilse hemen elenir. Sağlık heyetinin kararı kesin olduğundan kontrol sırasında mektep için uygun görülmeyen adaylar, bir daha muayeneye alınmaz ve imtihana kabul edilmez.

7 Ali İhsan Gencer, Bahriye'de Yapllan Islahat Hareketleri ve Bahriye Nezareti'nin Kuruluşu (İstanbul: Türk Tarih Kurumu, 2001): 30.

8 Nejat Gülen, Heybeliada (Tarihi, Coğrafyası, Yaşamı) (İstanbul: Tekin Yayınevi, 1985), 127.

9 Afif Büyüktuğrul, Osmanlı Deniz Harp Tarihi, cilt 3 (İstanbul: Deniz Basımevi, 1973), 244.

10 Askeri alanda gedik, savaşçı sınıfından sayılmadığı halde terfi ederek zabit olabilen askeri sınıfların kadroları için kullanılmıştır. Bkz. Ahmet Akgündüz, "Gedik" TDV İslam Ansiklopedisi, cilt 13 (İstanbul: Türkiye Diyanet Vakfi, 1996), 541-43.

11 Adnan Özyalçıner ve Şennur Sezer, Öyküleriyle İstanbul Anıtları I (İstanbul: Evrensel Basım Yayın, 2011), 7.

12 "Bahriye Efradının Küçük Zabitanıyla Gedikli Zabitanına Dair 22 Rebiyülahir 1333 [9 Mart 1915] Tarihli Kanunun 15. Maddesini Muadil Kanun, 5 Rebiyülahir 1335 /16 Kanun-i sani 1332 (29 Ocak 1917)," Düstur tertip 2, cilt 9 (1928), 134. Kanunun neşr ve ilanı için bkz. Takvim-i Vekayi 2782, 9 Rebiyülahir 1335 / 20 Kanun-i evvel 1332 (2 Şubat 1917), 2. 
Ayrıca, muayene ve imtihan sonucunda kabul edilmeyenlerin soru sorma ve itiraz hakları da bulunmaz. Bu muayene ile, eğitim sırasında deniz hayatının zorluk ve zahmetlerine tahammül edebilecek, sağlam bir bedene sahip olan askerlerin seçilmesi amaçlanmıştır. Gedikli olarak kabul edilecek askerlerin Osmanlı sahillerinde seyr-i sefer yapabilmek için yeterli gemicilik, ateşçilik, makinistlik, motorculuk, kılavuzluk, yağcılık, dalgıçlık, telsiztelgrafçılık, elektrikçilik, demircilik, tornacılık, tesviyecilik, dökümcülük, kalıpçılık ve gemi marangozluğu ile bunlara benzer deniz sanayisi konusunda bilgili olmaları şarttır.

Anılan kanuna göre kabul edilenler, Efrad-1 Cedide Mektebi'ne gönderilir. Beş ay mektepte ve ayrıca talim gemisinde eğitim aldıktan sonra donanmaya sevk edilirler. Askerler, büyük bir sağlık sorunu yaşamadıkça kara hizmetine gönderilmezler. Her sene Şubat ayının başında donanmada veya uygun yerlerde efradın sınavları yapılır. Bu sınav için amirin komutası altında bir sınav heyeti oluşturulur. Sınavlar, askere verilen eğitim ve talimler esas alınarak bir program çerçevesinde gerçekleştirilir. Sınavlarda başarılı olanlar ve hüsn-i hal sahibi olduğu amirleri tarafından onaylananlar gemilere gönderilirler. Şubat ayının sonuna kadar sınav sonuçları ilan edilerek kadrolar oluşturulur. Askerlerin terfii, Mart ayının sonunda başlar ve Nisan ayının beşine kadar da tamamlanır. Bu süre içinde askerin gemilere gönderilmesi tamamlanamazsa durum Bahriye Nezareti'ne bildirilir. Asker için yer bulunamadığında, gemilerde görevli olanlar başka yerlere gönderilerek gemilerde askere yer açılır.

Efrad-1 Cedide Mektebi'nde ihtiyaç varsa, gedikliler muallim olarak da istihdam edilebilir. Ancak, mektebe her sene yeniden muallim ataması yapıldığından sene sonunda görevlerine son verilir. Gediklilerin onbaşı ve çavuşluk için 1, gedikli namzetlerinin 2, gedikli zabitlerinin 3 sene görev yapmış olmaları gerekmektedir. Her rütbe için en az 1 sene denizde görev yapılması zorunludur. Gedikliler, nefer, ateşçi nefer, onbaşı, ateşçi onbaşı, çavuş, makine çavuşu, baş çavuşu, gedikli namzedi, 3. sınıf gedikli, 2. sınıf gedikli, 1 . sınıf gedikli rütbelerine ayrılır. ${ }^{13}$ Gedikli oldukları tarihten itibaren en az on sene hizmet edenler hakkında Askeri Tekaüd ve İstifa Kanunun 23. maddesi geçerlidir. Bu kanuna göre; üçüncü ve ikinci sınıf gediklilerden imtihan ile sınıfını terfi edemeyerek yeterlilik gösteremeyenler zorunlu olarak emekliye sevk edilir. Emeklilik sürelerini tamamlamadan görevlerine son verilenlere maaş bağlanmaz. Gediklilere, subaylar için olduğu gibi Askeri Tekaüd Kanununa göre maaş verilir. ${ }^{14}$

Gedikliler, cezalar konusunda da yine subaylar gibi Askeri Ceza Kanunu'na tabiidir. İki sene sonunda terfi sınavlarını kazanamayan veya kötü durumu ve sarhoşluğu alışkanlık

13 Efrâd-ı Bahriye ve Gedikliler Hakkında Kanunnâme-i Hümayun'a ([İstanbul]: Bahriye Matbaas1, 1915) göre 3. Sınıf gedikli maaşı 650; 2. Sınıf gedikli maaşı 1000; 1. Sınıf gedikli maaşı 1500 kuruştur. Muhripler ile torpidolarda istihdam olunacak gediklilere 100 kuruş, denizaltı ve tayyarelerde istihdam edilecek gediklilere ise 200 kuruş zam yapılarak senelik bir takım iş elbisesi verilmiştir. Başbakanlık Osmanlı Arşivi (BOA), Şuray1 Devlet (ŞD.TNZ), 24/2, 26 Rebiyülahir 1338 (18 Ocak 1920).

14 Meclis-i Ayan ve Meclis-i Mebusan tarafından kabul olunan bu layihanın kanuniyetini ve şartlarını devlete ilavesini irade eylerim. 16 Kanunisani 1332 / 5 Rebiyülahir 1335 (29 Ocak 1917), Mehmed Reşad (Sadrazam). 
ettiği sabit olan gediklilerin görevine son verilir. Bunlar, iki senelik zorunlu hizmetten muaf tutulur. Ancak, yalandan hastalanarak görevden kaçanlar bu haktan istifade edemez. Gedikliler, emeklilik konusunda yine subaylar gibi Askeri Tekaüd Kanunu'na tabi olmuşlar ise de, hizmete başlama tarihlerinden itibaren 17 seneyi tamamlamadan istifa edenlere bu hak verilmez. Gedikliler, zorunlu hizmetlerinin bitmesinden itibaren yedi sene sonra istifa hakkı kazanırlar. Ayrıca, zorunlu hizmetlerini tamamladıktan sonra istifa ederlerse askeri mükellefiyetlerini tamamlamış olarak kabul edilirler. 52 yaşını tamamlayan gedikliler, emekliye sevk edilir. Ancak, istifa ve emeklilik talepleri seferberlik zamanında kabul edilmez.

\section{Tayyareci Efradın (Tayyareci Askerlerin) Kurslarda Yetiştirilmesi}

Donanma askerlerinin savaşlar sırasında elde edilen tecrübeye bağlı olarak silahlı kuvvetlerde yapılan değişiklikler ve yenilikler hakkında eğitim almalarına karar verilmişti. ${ }^{15}$ Donanma askerlerinin mesleklerinde tecrübe elde ederek çalışmaları, maharet kazanıp işle ilgili bilgi kazanmaları için 20 Şubat 1917 tarihinde donanmanın zırhlı gemilerinde, denizaltılarında ve tayyarelerinde görevlendirilecek askerler için meslek kursları açılmıştı. ${ }^{16}$ Bahriye Nezareti tarafından hazırlanan programa göre kurslara devam zorunluluğu bulunuyordu. Kurslardaki eğitimlerinde başarılı olan askerler, rütbe ve kıdem zammı gibi mükâfatlar kazanmışlardır. ${ }^{17}$ Donanmada açılan ilk kurslar yabancı dil (İngilizce ve Fransızca) kurslarıydı. ${ }^{18}$ Kurslarda haftada 3 gün birer saat eğitim verilmekteydi ve devam zorunluydu. Katılacakların okur, yazar, çavuş veya baş çavuş rütbelerinde olmaları gerekiyordu. ${ }^{19}$ Deniz kuvvetleri tayyarelerinin silah ve makinelerinin yetkin bir şekilde kullanımı, bunların özelliklerinin iyi bilinmesine bağlıydı ve bu da uzun süreli eğitime ihtiyaç göstermekteydi. ${ }^{20}$ Bu sebeple, donanmada görev alacak tayyareci askerlerin bu kurslardan geçmeleri zorunlu tutulmuştu. Bahriye Nezareti İkinci Dairesi tarafından (7 Şubat 1332/20 Şubat 1917) tarihinde "Tayyareci Efradın Suret-i Duhul, Tahsil ve Terfileri Hakkında Talimatname" yayınlanmıştı. Bu talimatname esas alınarak Tayyare Mektebi’nin dışında olmak üzere Efrad-ı Cedide Kışlası’nda “Tayyareci Namzetleri Kursu"nda eğitime başlandı. Eğitim programları zaman zaman değişikliklere uğramak üzere Bahriye Nezareti Üçüncü Daire ve İkinci Dairesi tarafindan belirlenmişti. ${ }^{21}$

Efrad ve gediklilerin tayyareci asker olabilmeleri için bazı vasıfları taşımaları gerekirdi. Tayyareci askerleri için hazırlanan talimatnameye göre, 19 yaşından küçük ve 30 yaşından büyük olanlar kabul edilmemişlerdi. Tayyareci asker olarak görev yapabilmeleri için sağlıklarının özellikle kalp ve sinirlerinin çok iyi olması gerekiyordu. Yaş için sadece yazılı

15 Deniz Müzesi Arşivi (DMA), Bahriye Dairesi Riyaseti (BD.R), 12/220-1, 20 Haziran 1329 (20 Haziran 1913).

16 DMA, III. Daire, 30/8, 20 Șevval 1331 (22 Eylül 1913).

17 DMA, BD.R, 7/118-12, 12 Şubat 1328 (25 Şubat 1913).

18 BOA, İrade Meclis-i Mahsus (İ.MMS), 170/25, 29 Zilkade 1331 (30 Ekim 1913).

19 DMA, BD.R, 12/220-1, 12 Haziran 1329 (25 Haziran 1913).

20 BOA, Meclis-i Vükela (MV), 231/346-1-1, 9 Şubat 1332 (22 Şubat 1917).

21 DMA, Bahriye Nezareti (BN), 327/10720, 7 Şubat 1332 (20 Şubat 1917). 
vesika esas alınmamış, aynı zamanda adayların vücutlarının hali ve akli durumlarının da o yaşta görünmesine dikkat edilmişti. Adaylar, yabancı dil öğrenebilecek bir seviyede olup, pusula, harita, motor hakkında bilgi sahibi, ayrıca tayyarecilik için yeteri kadar heves ve arzuları olmalıydı. Doktorlar tarafından yapılacak sağlık kontrolünde tayyarelerde görev alacak kadar yeterli oldukları kanıtlanmalıydı. ${ }^{22}$

Tayyareci Namzetleri Kursu’nda talebelerin bilgi ve becerilerini genişletmek üzere eğitim programları hazırlanmıştı. ${ }^{23}$ Kurslarda verilen eğitim, mesleki bilgiler esas alınarak iki döneme ayrılmıştı. Birinci dönem dört ay, ikinci dönem altı ay sürecekti. Ancak, bu süre askerlerin kazandığı tecrübe ve eğitime göre azaltılabilir, uzatılabilir veya değiştirilebilirdi. Tayyareci asker olarak kabul edilecek efradın bu görev için yeterli, mesleğine kabiliyetli, Efrad-ı Cedide Mektebi'nde eğitimini tamamlamış ve sağlıklı olması ve görevini bırakmayacağını taahhüt etmesi gerekirdi. Tayyareci askerlerinin ölçülü ve hızlı karar verebilen, mesleğe yeterli kişilerden seçilmesine özen gösterilirdi. Özellikle makineci çırakları eğitimlerini tamamlamalarından sonra ihtiyaca göre tayyareci asker olarak kabul edilmişlerdir. Efrad ve gediklilerin dışında diğer askerler de eğitimlerini tamamladıktan sonra tayyareci askerliği için yeterli olduklarını kanıtlamaları halinde kurslara gönderilmişlerdir. Tayyareci askerler, hastalık nedeniyle derslere devam edemedikleri takdirde bunların yeniden eğitim almaları zorunludur. ${ }^{24} \mathrm{Bu}$ eğitimi tamamlayarak sınavlarında başarılı olanlara bir derece terfi verilir.

Tablo 1. Tayyareci Asker Kursunun Birinci Dönem Sinav Program125

\begin{tabular}{|l|l|l|}
\hline & 1. İmtihan & 2.İmtihan \\
\hline Çarşamba & Fizik & Hifz-1 sıhha \\
\hline Perşembe & Ser-dümenlik & Akaid-i diniyye \\
\hline Cumartesi & Coğrafya & Terbiye-yi askeriye \\
\hline Pazar & Hesap & İşaret \\
\hline Pazartesi & Hendese & Terbiye-yi bedeniyye ve jimnastik \\
\hline Salı & Lisan-1 Osmani & Talim \\
\hline Çarşamba & Motorculuk & \\
\hline
\end{tabular}

Kurslar sonunda yapılan sınavlarda başarılı olamayanlar tekrar kurslarda eğitim almışlardır. Kurslara veya sınavlara girmeyen tayyareci askerler hakkında inceleme yapılmıştır. Geçerli bir sebebi olmadan kurs sonunda yapılan sınavlara girmeyenler haklarını kaybetmiş sayılmıştır. Kurslar sonunda askerlerin sınavdan aldıkları notlar aşağıdaki gibi listeler halinde yayınlanmıştır. ${ }^{26}$

22 DMA, BN, 162/2748.

23 DMA, BD. R, 7/118-12, 18 Kanun-i sani 1340 (18 Ocak 1924).

24 DMA, BN, 327/10720, 7 Şubat 1332 (20 Şubat 1917).

25 DMA, BN, 346/12383, 11 Temmuz 1333 (24 Temmuz 1916), Terbiye-yi Bedeniye - Jimnastik ve Talimden başka diğer derslerin sınavları yazılı yapılmıştır.

26 DMA, Mülga Bahriye (MB), 94/85, 20 Şubat 1331 (4 Mart 1916). 
Tablo 2. Tayyareci Asker Kursunda Hendese [Geometri] Dersi Sınav Sonuçlar1 ${ }^{27}$

\begin{tabular}{|c|c|c|c|}
\hline Sira No & İsmi & Rütbesi & Notu \\
\hline 1 & Dersaadetli Ali oğlu Tarhan & Onbaş1 & $100+$ \\
\hline 2 & Silifkeli Ahmed oğlu Feyzi & “ & $100+++$ \\
\hline 3 & Katmanlı İbrahim oğlu Ali Rıza & “ & $100+++$ \\
\hline 4 & Malkaralı Abdullah oğlu Asaf & “ & $100+$ \\
\hline 5 & Kasımpaşalı Mehmed oğlu Latif & Nefer & $100+$ \\
\hline 6 & Kanlıcalı Halil oğlu Fethi & Onbaşı & 100 \\
\hline 7 & Gelibolulu Şevket oğlu Rıza & Çavuş & $100+$ \\
\hline 8 & Rizeli Hüseyin oğlu Ahmed & Onbaşı & 100 \\
\hline 9 & Ünyeli Emin oğlu Asım & Nefer & 100 \\
\hline 10 & Bursalı Ali oğlu Refik & Onbaşı & 100 \\
\hline 11 & Dersaadetli Ahmed oğlu Fethi & Onbaşı & $100+$ \\
\hline 12 & İzmirli Süleyman oğlu Ahmed & Çavuş & 99 \\
\hline 13 & İzmitli Hüseyin oğlu Abdullah & Onbaşı & $100+$ \\
\hline 14 & Beykozlu Nuri oğlu Hulusi & Nefer & 100 \\
\hline 15 & Kasımpaşalı Hüseyin oğlu Ali Rıza & Onbaşı & 100 \\
\hline 16 & Bandırmalı Hasan oğlu Hikmet & Nefer & 100 \\
\hline 17 & Eriklili Mustafa oğlu Raif & Çavuş & 97 \\
\hline 18 & Üsküdarlı Hüseyin oğlu Mustafa & Nefer & 100 \\
\hline 19 & Dersaadetli Yusuf oğlu Sadık & Nefer & 100 \\
\hline 20 & Rizeli Raif oğlu Mahmud & Nefer & 100 \\
\hline 21 & Bandırmalı Yakup oğlu Emin & Onbaşı & 100 \\
\hline 22 & Bandırmalı Eyüb oğlu Mustafa & Nefer & 100 \\
\hline 23 & Trebolulu Veli oğlu Salih & Onbaşı & 100 \\
\hline 24 & Dersaadetli Hüseyin oğlu Ahmed & Onbaş1 & 100 \\
\hline 25 & Trabzonlu Hakkı oğlu Salih & Onbaşı & 100 \\
\hline 26 & Dersaadetli Eyüb oğlu Rıza & Nefer & 90 \\
\hline 27 & Antalyalı Galib oğlu Mustafa & Nefer & $100+$ \\
\hline 28 & Dersaadetli Ferhad oğlu Yaşar & Nefer & 100 \\
\hline 29 & İzmirli Bekir oğlu Hüseyin & Onbaşı & 97 \\
\hline 30 & Yalovalı Mustafa oğlu Halil & Nefer & 100 \\
\hline 31 & Dersaadetli Mustafa oğlu Süleyman & Nefer & 98 \\
\hline
\end{tabular}

27 DMA, BN, 346/12383. Aynı arşiv dosyası içinde Akaid-i Diniye, Terbiye-yi Askeriye, Terbiye-yi Bedeniye Jimnastik derslerine ait sınav sonuçları vardır. 


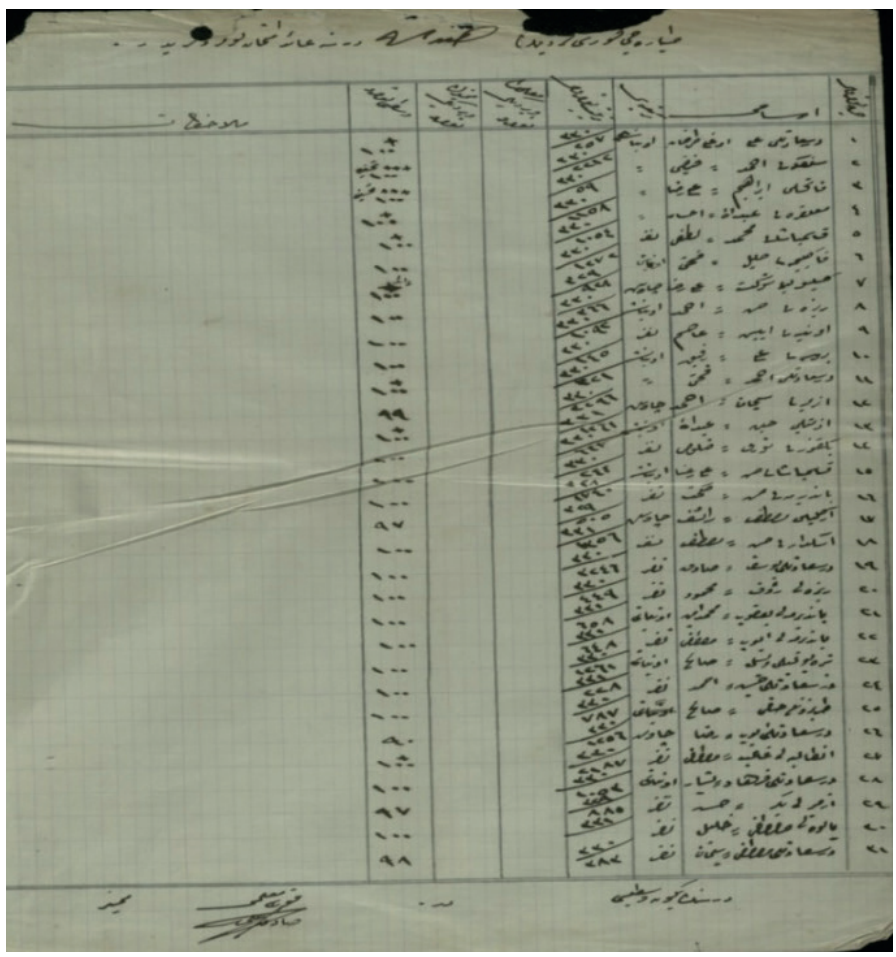

“Tayyareci Kursu Efradının Hendese Dersine Aid İmtihan Numaralarıdır” (DMA, BN, 346/12383)

Kurslarda eğitim verecek muallimler, çarkçı ve güverteciler arasından seçilmişlerdir. Okulda her sene muallimler değiştirilerek yenileri görevlendirilirdi. Kurslarda öğretmenlerin yemekleri ve diğer masrafları karşılanırdı. Ayrıca, başarılı bir şekilde eğitim veren muallimlere mükâfat olarak kıdem verilirdi. Tayyareci askerlerin eğitim programında, zaman zaman yenilikler ve değişiklikler yapılırdı. Efrad-1 Cedide Mektebi Tayyareci Kursu muallimi Mülazım Kasımpaşalı Mehmed Sadık Efendi, daha iyi eğitim verebilmesi için Yeşilköy'deki Tayyare Mektebi'nde rasat kursuna gönderilmişti. Eğitim sırasında tayyareci ve rasat muallimi olarak maaşına zam yapılmıştır. Muallim Sadık Efendi, rasat eğitiminden sonra Efrad-1 Cedide Mektebi tayyareci askerlerine her ayın Salı günü hava müsait oldukça meydan uçuşu ve tarassud (gözlem) yaptırmıştır. Rasat eğitiminin sonunda tayyarecileri sınav yaparak başarılı olanları belirlemiştir. ${ }^{28}$

Deniz tayyarelerinde görevlendirilen 16 acemi asker ihtiyacı karşılamamıştır. Askerlerin görevlerine hazırlanmasına ve gönderilecek olan yeni tayyareci askerlerin bu görevi yapabilecek seviyede olmalarına dikkat edilmiştir. Tayyareci askerlerin konuları daha iyi anlayabilmeleri, uygulama yapmalarına bağlıydı. Bu amaçla, 24 adet tayyare sipariş etmesi

28 DMA, BN, 346/12383, 11 Temmuz 1333 (11 Temmuz 1917). 
için Berlin Sefareti'ne talimat gönderilmiştir. Bir süre sonra tayyareci askerlerin talimlerinde kullanılmak üzere Almanya'dan bir aylı̆̆ına bir Albatros Tayyaresi gelmiştir. Donanmada ikinci tayyare bölüğü için tayyareci askerlerine ihtiyaç duyulunca deniz tayyare müfrezesinden 11 asker görevlendirilmiş ve bunlar Efrad-1 Cedide Mektebi'nde eğitim almaya başlamıştır (20 Ekim 1917). ${ }^{29}$

\section{İzinleri ve Maaşları}

Donanma askerlerine senede bir ay, hizmet ve gayretleri ile başarı gösterenlere ise iki ay kadar izin verilirdi. Hizmete yeni başlayanlar, ilk altı ay içinde mecbur olmadıkça izin alamazdı. Ayrıca, izinli gittikleri mahallerde donanma kumandanına ya da askeri kumandanlığa 24 saat içinde ikamet yerlerini bildirmek zorunda idiler. ${ }^{30}$

Efrad ve gediklilerin eğitimleri sırasında talim ve manevra zamanlarına mahsus ücretlerinden başka her saat için beş kuruş verilmiştir. ${ }^{31}$ Kurslarda eğitimlerini başarılı bir şekilde tamamlayanlar tayyareci asker olabilmeleri için Yeşilköy'deki Tayyare Mektebinde beklemişlerdir. Tayyareci askerler, görev yerlerinin belirlenmesine kadar askeri maaşlarına ilaveten, iki yüz kuruş "Nefer Tayin Bedeli" almışlardır. ${ }^{32}$ Tayyareci olarak istihdam olunan bütün gediklilere görevlerine başlamalarından itibaren rütbeleri dikkate alınmaksızın gerek öğrencilik ve gerekse tayyarecilik zamanlarında maaşlarına sekiz Osmanlı lirası zam yapılmıştır. Bu kanunun uygulanmasından hem Bahriye Nezareti hem de Maliye Nezareti sorumlu olmuştur. ${ }^{33}$ Tayyarelerde istihdam olunan gedikli, küçük zabitan ve efradın maaşına yapılacak zam ${ }^{34}$ hakkında Bahriye Nezareti tarafından bir layiha hazırlanmıştır. ${ }^{35} \mathrm{Bu}$ layihaya göre, efrad ve gediklilere göreve başlamalarından itibaren rütbelerine göre maaşlarının yarısı kadar zam yapılmıştır. ${ }^{36}$ Tayyareci öğrencilere, kurslarda iki dönem boyunca eğitimlerini tamamladıktan sonra iki yüz kuruş maaş verilerek görev yerlerine gönderilmişlerdir. Makineci çırakları, kurslardaki eğitimlerde başarılı olarak tayyareci askeri olarak görevlendirildiklerinde bir derece terfi edilmiş ve maaşlarına zam yapılmıştır. Tayyareci öğrenciler ve tayyareci askerler, hastalık veya kaza sonucunda derslerle talimlere devam edemezlerse, bunlar aynı sınıfı yeniden okur veya görev yerleriyle ilgili değişiklik yapılırdı. Bir süre sonra silahaltında bulunan 1895, 1896, 1897 doğumlu deniz tayyarecilerinin hem göreve başlamaları hem de terhislerinden sonra emeklilikleri için silahaltında geçirdikleri sürenin dikkate alınmasına karar verildi (20 Ekim 1917). ${ }^{37}$

29 DMA, BN, 346/12383, 27 Ağustos 1333 (27 Ağustos 1917).

30 DMA, Umuru Bahriye Müdüriyeti II (U.BM II), 17/312-7, 18 Teşrinisani 1340 (18 Kasım 1924).

31 BOA, İrade Meclis-i Mahsus (İ.MMS), 185/19-4-2, 18 Mayıs 1330 (31 May1s 1914).

32 BOA, Babıali Evrak Odası (BEO), 4394/329526-2-2, 4 Kanun-i sani 1331 (17 Ocak 1916).

33 BOA, BEO, 4394/329526-3-1, 11 Rebiyülevvel 1334 (17 Ocak 1916).

34 BOA, BEO, 4394/329526-1-1, 4 Kanun-i sani 1331 (17 Ocak 1916).

35 BOA, BEO, 4394/329526-1-2, 4 Kanun-i sani 1331 (17 Ocak 1916).

36 BOA, BEO, 4394/329526-2-1, 4 Kanun-i sani 1331 (17 Ocak 1916).

37 BOA, İrade Dosya Usulü (İ.DUİT), 87/9, 20 Ekim 1917. 


\section{Kıyafetleri}

Tayyareci askerlerin kılık kıyafetlerine oldukça özen gösterilmişti. Gediklilerin resmi elbiselerine dair bir talimatname hazırlanmıştı. Buna göre, gediklilerin serpuşları subaylarınkine benzerdi. Sadece, subayların serpuşlarında bulunan sırma şerit gediklilerin serpuşlarına yoktu. ${ }^{38}$ Efrad ve gedikli ceketlerinin omuzluklarındaki rütbe ve işaretler bulundukları sınıflar dikkate alınarak hazırlanmıştı. Eğitimleri sırasında giydikleri barut rengi çuha kumaşından yapılmış pantolon, subaylarınkiyle aynıydı. Ceketleri dik yakalı ve yakayı iliklemek için iki kopçalı önü tek sıra beş düğmeli ve göğsün sol tarafında düğmelerin istikametinde kapaklı iki cebi ve her iki arka dikişlerinin alt kısımlarında 13 santimetre yırtmaçları bulunurdu. Şeritler ile alametler, efrad ve gediklilere uygun bir şekilde takılırdı. Subayların giydiği gibi beyaz ceketleri olacak, ancak rütbe ve ihtisas alametlerini gösteren omuzluklardaki işaretler için talimatname esas alınacaktı. Pantolonlarında apolet ile köprü bulunmayacaktı. Uzun kılıç kullanılacak ve buna mahsus kılıç püskülü takılacaktı. Ayrıca, uzun kılıçların deve derisinden üretilen kayışları olacaktı. Bunların dışında boyun bağı, eldiven, potin, düğmeler, beyaz potin ve kolalı gömlekleri bulunacaktı. Birinci sınıf gedikliler, subayların tabi oldukları şartlar dâhilinde, ikinci ve üçüncü sınıf gedikliler ise mezun olana kadar askeri mevkiler dışında sivil elbise giyeceklerdi. Gedikliler uzun kılıcı yalnız sıcak havalarda beyaz eldiven ile beraber giyilen elbise ile takabileceklerdi. Mahkeme gibi adli kurumlarda beyaz elbise ve k1lıç takmaları ise yasaktı. ${ }^{39}$

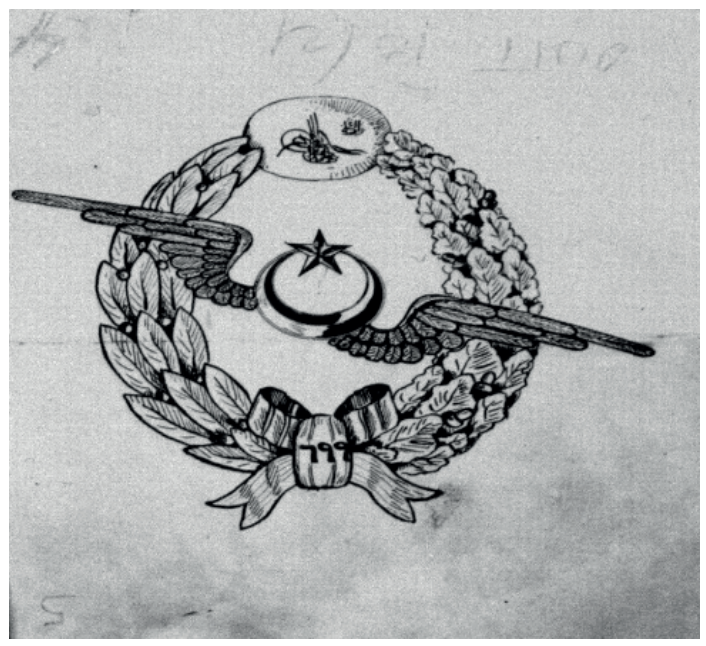

Tayyareci askerlerin kıyafetlerinde kullanılmış olması muhtemel işaret (BOA, İ.DUIT, 19/21-4-2)

38 DMA, Mülga Bahriye (MB), 625/317, 25 Nisan 1334 (25 Nisan 1918).

39 DMA, BN, 380/13820. 


\section{Terfileri}

Tayyareci askerlerin terfileri gemi, tersane ve diğer donanma efradının terfilerinden farklı olmuştur. Bahriye Nezareti İkinci Dairesi tarafından 20 Şubat 1917 tarihinde tayyareci askerlerinin eğitim ve terfileri hakkında bir talimatname yayınlanmıştı. Tayyareci Efradı Talimatnamesi'ne göre; birinci ders döneminin sonunda asker, on başı, çavuş ise, terfi edeceği rütbe onbaşı, çavuş, baş çavuştur. İkinci ders döneminin sonunda onbaşı, çavuş ise terfi edeceği rütbe çavuş, baş çavuştur. Tayyareci efradı ve gedikliler, kurslarda başarılı olamazlarsa ya aynı ders dönemini tekrar etmişler ya da ihraç edilmişlerdir. ${ }^{40}$

\section{Sonuç}

Yaşadı̆̆ı ağır savaşlarda, Osmanlı Devleti, tayyarelerin, sahillerin korunması ve donanmanın güçlendirilmesinde de önemli bir silah olduğu fark etmiştir. Deniz Kuvvetlerinin tayyarelerinde görev alacak elemanlara ihtiyaç duyulduğu için Yeşilköy'de Tayyare Mektebi açılarak ihtiyaç karşılanmaya çalışılmıştır. Tayyare Mektebinin dışında olmak üzere Efrad-ı Cedide Kışlası'nda “Tayyareci Namzetleri Kursu” açılarak donanma askerlerine kurslarda eğitim verilerek 'tayyareci asker'ler yetiştirilmiştir. Bu kursların amacı; Tayyare Mektebi’ndeki mesleki bilgileri esas alarak asker yetiştirmekti. Efrad ve gedikliler, kurslarda eğitim ve terbiye aldıktan sonra eğitimlerini tamamlayarak 'tayyareci asker' olarak görevlendirilirdi. Üç tarafı denizlerle çevrili olan Anadolu'da yaşayan devletler, kuvvetli bir donanmaya sahip olmak zorundaydı. Ancak, dünyada başlayan en büyük değişimlerden biri de gökyüzünden gelebilecek saldırılardı. Tayyareler düşman hakkında bilinmesi gereken bütün malumatı kısa zamanda keşfedebilmekteydi. Her alanda derin izler bırakan bu önemli icat, savaş sırasında çok önemli bir silahtı. Bu durum nazarı dikkate alınarak donanmada da tayyare kullanılmıştır. Donanmada kullanılmaya başlanan tayyarelerde görev almaları için tayyareci asker yetiştirilerek eleman yetersizliği giderilmeye çalışılmıştır.

Finansal Destek: Yazar bu çalışma için finansal destek almamıştır.

\section{KAYNAKÇA / BIBLIOGRAPHY}

\section{Arşiv Kaynakları / Archival Sources}

\section{Başbakanlık Osmanlı Arşivi (BOA)}

Babiali Evrak Odas1 (BEO), 4394/329526-1-1, 4394/329526-1-2, 4394/329526-2-1. 4394/329526-2-2, 4394/329526-3-1,11 Rebiyülevvel 1334 (17 Ocak 1916).

İrade Dosya Usulü (İ.DUİT), 87/9.

40 DMA, BN, 327/10720, 1332 (4 Temmuz 1917). Tayyareci Efradın Suret-i Duhul, Tahsil ve Terfileri Hakkında Talimatname, (117 Numaralı Emirnamedir). 
İrade Meclis-i Mahsus (İ.MMS), 185/19-4-2, 18 Mayıs 1330 (31 May1s 1914), 170/25, 29 Zilkade 1331 (30 Ekim 1913).

Meclis-i Vükela (MV), 231/346-1-1.

Şura-yı Devlet (ŞD.TNZ), 24/2, 26 Rebiyülahir 1338 (18 Ocak 1920).

Deniz Müzesi Arşivi (DMA)

Bahriye Dairesi Riyaseti (BD. R), 7/118, 18 Teşrinisani 1340 (18 Kasım 1924), 12/220-1, 12 Haziran 1329 (25 Haziran 1913).

Bahriye Nezareti (BN), 327/10720, 4 Temmuz 1332 (4 Temmuz 1917), 162/2748, 380/13820, 12 Temmuz 1332 (25 Temmuz 1916), 346/12383, 11 Temmuz, 1333 (11 Temmuz 1917), Mülga Bahriye (MB), 94/85, 20 Şubat 1331 (4 Mart 1916), 625/317, 25 Nisan 1334 (25 Nisan 1918).

Umuru Bahriye Müdüriyeti II (U.BM II), 17/312-7, 1 Mart 1340 (1 Mart 1924).

III. Daire, 30/8, 20 Şevval 1331 (22 Eylül 1913).

\section{Basılı Kaynaklar / Printed Sources}

Akgündüz, Ahmet. “Gedik.” TDV İslam Ansiklopedisi. 13:541-543 İstanbul: Türkiye Diyanet Vakfı, 1996.

“Bahri Tayyareler.” Mecmua-i Fünun-ı Bahriye 20, 9 (Teşrin-i Sani 1338): 168-171.

“Bahriye Efradının Küçük Zabitanıyla Gedikli Zabitanına Dair 22 Rebiyülahir 1333 [9 Mart 1915] Tarihli Kanunun 15. Maddesini Muadil Kanun, 5 Rebiyülahir 1335 /16 Kanun-i sani 1332 (29 Ocak 1917).” Düstur tertip 2, cilt 9 (1928): 134.

Büyüktuğrul, Afif. Osmanlı Deniz Harp Tarihi, cilt 3. İstanbul: Deniz Basımevi, 1973.

Efrâd-ı Bahriye ve Gedikliler Hakkında Kanunnâme-i Hümayun. [İstanbul]: Bahriye Matbaası, 1331 (1915).

Gencer, Ali İhsan. Bahriye’de Yapılan Islahat Hareketleri ve Bahriye Nezareti'nin Kuruluşu. İstanbul: Türk Tarih Kurumu, 2001.

Gülen, Nejat, Heybeliada (Tarihi, Coğrafyası, Yaşamı). İstanbul: Tekin Yayınevi, 1985.

“Gemiden Sonra Tayyare.” Tayyare Cemiyeti Mecmuası 17, 23 (1 Mart 1926): 3-4.

“Hava Devri.” Tayyare Cemiyeti Mecmuası 17, 11 (1 Kanun-i evvel 1925): 1-2.

Kurt, Deniz, ve Erdal Korkmaz. "Yeni Arşiv Belgeleri Işı̆̆ında Türk Askerî Havacılığının Doğuşu (19111912)." Savunma Bilimleri Dergisi 17, 2 (2018): 207-251.

Özyalçıner, Adnan ve Şennur Sezer. Öyküleriyle Ístanbul Anıtları I. İstanbul: Evrensel Basım Yayın, 2010.

Takvim-i Vekayi 2782, 9 Rebiyülahir 1335 / 20 Kanun-i sani 1333 (2 Şubat 1917), 2.

“Tayyarelerin Ehemmiyeti Harbiyeleri." Ordu ve Donanma Dergisi 2 (Nisan 1328 / 1912): 43-47.

Yeni, Mustafa. "Hava Kuvvetleri.” Dünya Savaş Tarihi: Osmanl Askeri Tarihi, Kara, Deniz ve Hava Kuvvetleri 1792-1918, editör Gültekin Yıldız içinde, 165. İstanbul: Timaş Yayınları, 2013. 